\title{
Tradução de teatro: um paradigma a partir do El borde, de Amancay Espíndola
}

\author{
Tereza Virgínia Ribeiro Barbosa, Anna Palma, Amanda Bruno de \\ Mello, Anita Mosca, Carlos Eduardo de Souza Lima Gomes, Jéssica \\ Tamietti de Almeida, Maria Silvia Duarte Guimarães e Vanessa Ribeiro \\ Brandão *
}

\section{Introdução}

Apresentamos uma tradução coletiva, funcional e colaborativa do monólogo El borde, de Amancay Espíndola, atriz e dramaturga (formou-se pela Facultad de Filosofía y Letras da Universidad de Buenos Aires em Artes Combinadas) argentina. Amancay obteve, ao longo da carreira, vários prêmios, entre eles, o Prêmio Nacional de Dramaturgia (conferido pela Secretaria de Cultura da Nação, em 1997). Suas obras mais conhecidas são: Crónica de las Indias, editado pelas Abuelas de Plaza de Mayo / Ministerio de Educación, Ciencia y Tecnología; Esclava del alma, Editorial Eudeba; El Bar y la Novia, Editorial Nueva Generación; Herencia de sangre, Editorial Amaranta.

A intenção de nossa empreitada com o tipo de tradução que nomeamos "coletiva, funcional e colaborativa" é propor um trabalho de fronteira entre o acadêmico e o artístico. Portanto, estaremos atuando no limite de duas áreas que têm práticas distintas na abordagem do texto teatral. Vários teóricos diagnosticaram o problema, entre eles Raquel

\footnotetext{
* Os autores pertencem ao GTT/CNPq, Grupo (de Pesquisa) de Tradução Teatral vinculado aos grupos de pesquisa do CNPq que desenvolve investigação sobre a tradução de textos vinculada à preocupação dramatúrgica. Tereza Virgínia Ribeiro Barbosa é Professora Titular da UFMG. Anna Palma é Professora Adjunta da UFMG. Amanda Bruno de Mello é graduanda em Letras pela UFMG. Anita Mosca é atriz, diretora e dramaturga. Graduada em Letras pela UFMG. Carlos Eduardo de Souza Lima Gomes é doutorando na UFMG. Jéssica Tamietti de Almeida é mestranda na UFMG. Maria Silvia Duarte Guimarães é graduanda na UFMG. Vanessa Ribeiro Brandão é mestre e doutoranda na UFMG.
} 


\title{
Merino Álvarez (2011), Rosa Currás-Móstoles e Miguel Ángel Candel- Mora. Esses últimos formulam a questão de modo sucinto e elucidativo:
}

\begin{abstract}
Existem dois tipos de pesquisadores no campo da tradução teatral: aqueles que, provenientes de outros campos de estudo, como a filologia, a literatura comparada ou a linguística, se ocupam da tradução (em sentido global e específico) de obras dramáticas e por isso, de uma parcela dos estudos da tradução; e do outro lado, os profissionais do campo dramático (atores, diretores, técnicos, dramaturgos, tradutores dramáticos, etc.) que refletem sobre suas tarefas dentro do teatro, apesar de que desses últimos se desaprova que ignorem as contribuições da semiologia do teatro, e que se centrem na representação e nos aspectos não verbais da mesma em detrimento do texto literário. (Currás-Mostoles, Candel-Mora, 2011, p. 38) [Tradução nossa $]^{1}$
\end{abstract}

Há, portanto, um fosso entre o texto da prateleira e a cena. O diagnóstico é confirmado por vários outros teóricos da tradução teatral.

Existe pouco material sobre a tradução teatral em termos gerais, porém entre os textos aos quais se teve acesso se encontram breves menções à tradução teatral em volumes sobre teoria da tradução em geral (como no caso de Newmark, 1992 e Hurtado Albir, 2001); assim como os que dedicam capítulos de livros ao tema (Arrowsmith e Shattuck, 1961; Bassnett, 1980; Santoyo, 1985; Corvin, 1991; Alonso de Santos, 2007); se destacam os que tratam os estudos descritivos sobre tradução e os que se ocupam de problemas pragmáticos, linguísticos ou lexicais específicos na hora de traduzir autores consagrados como Shakespeare ou outros (Warren, 1974; Zuber-Skerritt, 1980; Conejero, 1982; Merino, 1994; Aragón, 1996; Toury, 2004); há também os estudiosos de tradução como processo e aqueles cujas preocupações têm a ver com o contexto cultural e como esse influi no resultado final da tradução (Corrigan, 1961; Nowra, 1984; Koustas, 1989; Bassnett e Lefevere, 1990; Brisset, 1990; Pavis, 1990; Déprats, 1991; Ubersfeld, 1997; Grass, 2003; Nicolarea, 2005; Villacampa, 2005; Hermans, 2006, vols. 1 e 2; Piña, 2007); e, por último, os que se ocupam da transposição do texto para a cena ou para outro meio como a televisão, o cinema e o rádio (Zuber-Skerritt, 1984; Törnqvist, 2002;

\footnotetext{
1 “Existen dos tipos de investigadores en el campo de la traducción teatral: aquellos que provenientes de otros campos de estudio, como la filología, la literatura comparada o la lingüística se ocupan de la traducción (en sentido global y específico) de obras dramáticas y por lo tanto, de una parcela de los estudios de traducción; y por otro lado, los profesionales del campo dramático (actores, directores, técnicos, dramaturgos, traductores dramáticos, etc.) que reflexionan sobre su quehacer dentro del teatro, si bien a estos últimos les reprocha que ignoren las aportaciones de la semiología del teatro, y que se centren en la representación y los aspectos no-verbales de la misma en detrimento del texto literário".
} 
Romera Castillo, 2006, 2007). (Fernández, 2010, p. 133-134) [Tradução nossa $]^{2}$

Ao quadro teórico mundial apresentado, acrescente-se ainda que há, como se sabe (pelo menos em relação ao teatro antigo no Brasil), traduções teatrais que nunca foram encenadas. Procurando reverter, no Brasil, o panorama relatado pelos pesquisadores citados, objetivamos, além de testar e consolidar uma nova metodologia de tradução, a que pensa a sintonia texto-cena, operacionalizamos a tradução do pequeno monólogo $E l$ borde exercitando um olhar crítico seja sobre o processo tradicional da tradução interlingual, seja sobre a execução textual e cênica habitual nos palcos.

Nossa metodologia tenta diminuir a distância entre o texto da partitura escrita e o texto oralizado para a cena; seu aspecto inovador se deve à prática de um fazer coletivo - desde a análise literária do texto na língua original até a sua oralização com sucessivos testes de realização, isto é, performances propriamente ditas - e transdisciplinar.

De fato, o grupo realiza o trabalho de tradução e pesquisa em conjunto com os profissionais das várias áreas que envolvem o teatro. Desse modo, conta-se, simultaneamente e a cada reunião de trabalho, com a colaboração de pesquisadores das áreas das ciências da linguagem que trabalham apenas com textos e de artistas (atrizes, diretoras de cena, cenógrafos, produtores, músicos etc.) cujo material principal é o corpo. Nos encontros são analisados e comentados textos teóricos sobre tradução em

\footnotetext{
2 “Existe poco material sobre la traducción teatral en términos generales, pero entre los textos que se logran rescatar se encuentran breves menciones a la traducción teatral en compendios sobre teoría de la traducción en general (como el caso de Newmark, 1992 y Hurtado Albir, 2001); así como aquellos que dedican capítulos de libros al tema (Arrowsmith y Shattuck, 1961; Bassnett, 1980; Santoyo, 1985; Corvin, 1991; Alonso de Santos, 2007); destacan aquellos que tratan los estudios descriptivos sobre traducción y los que se ocupan de problemas pragmáticos, lingüísticos o léxicos específicos a la hora de traducir autores consagrados como Shakespeare u otros (Warren, 1974; Zuber-Skerritt, 1980; Conejero, 1982; Merino, 1994; Aragón, 1996; Toury, 2004); también están los estudios de traducción como proceso y aquellos cuyas preocupaciones tienen que ver con el contexto cultural y como éste influye en el resultado final de la traducción (Corrigan, 1961; Nowra, 1984; Koustas, 1989; Bassnett y Lefevere, 1990; Brisset, 1990; Pavis, 1990; Déprats, 1991; Ubersfeld, 1997; Grass, 2003; Nicolarea, 2005; Villacampa, 2005; Hermans, 2006, vols. 1 y 2; Piña, 2007); y, por último, los que se ocupan de la transposición del texto a la escena o a otro medio como la televisión, el cine o la radio (Zuber-Skerritt, 1984; Törnqvist, 2002; Romera Castillo, 2006, 2007)".
} 
geral e outros mais específicos sobre tradução teatral. Além disso, praticam-se, sistematicamente, traduções em movimento (work in progress) das quais $O$ Limite é um resultado. A prática consiste em fazer com que as propostas tradutórias circulem, sejam debatidas e criticadas a partir das diversas formas de atuação dos integrantes do grupo e até serem consideradas funcionais para o teatro. Estabelecido o texto de apoio, os artistas envolvidos no processo erguem um pequeno espetáculo e, após a encenação, a tradução que já foi encenada pelos atores pertencentes ao grupo é reanalisada e, se considerado necessário, modificada.

O suporte teórico do grupo é variado. Recorremos prioritariamente a todos os autores que discutem a tradução teatral na perspectiva de uma poética, ou seja, de uma maneira de fazer - ou refazer - um texto esteticamente comprometido. Um bom autor para este viés é Henri Meschonnic. Para ele, e isso é importante na especificidade de uma tradução para a cena, a maneira de se fazer e refazer uma tradução não deve ser encarada como uma ciência, mas como um exercício crítico; crítico de si mesmo e crítico do outro. Com este escopo, estar em um grupo onde se divide confiança e transparência é altamente positivo para o exercício da crítica. Meschonnic afirma igualmente que a poética da tradução é "uma teoria crítica no sentido em que ela se encontra como teoria de conjunto da linguagem, da história, do sujeito e da sociedade, e também no sentido em que ela se funda como teoria da historicidade radical da linguagem" (Meschonnic, 2010, p. 4-5).

De acordo com a citação, traduzir é um ato poético consciente de uma política tanto com relação ao pensamento do autor quanto com relação ao do tradutor (e no nosso caso, dos tradutores); ato poético e político no qual o estatuto do sujeito é capital. Por isso, desde a escolha dos textos, da dicção, da destinação através da tradução desta ou daquela maneira, tudo para nós é um fazer político. Resguardamos sempre a função do texto, a saber, do texto escrito para ser encenado por e para muitos.

Além de Meschonnic, privilegiamos igualmente outros teóricos que veem o texto teatral como um discurso contextualizado já que, ainda segundo Meschonnic, "o discurso supõe o sujeito, inscrito prosódica e ritmicamente na linguagem, [com] sua oralidade, sua física." (Meschonnic, 
2010, p. 16). Assim, pensar a tradução teatral sem contextualizá-la passa a ser impossível. Como exorta Patrice Pavis (2008, p. 127), compreendemos que o tradutor de teatro é um dramaturgo que deve, em primeiro lugar, efetuar a tradução macrotextual e a análise dramatúrgica da obra cuidando especialmente de sua totalidade artística, ou seja, do sistema de personagens, do espaço e do tempo, do ponto de vista ideológico e, evidentemente, diante de tudo isso, esmerar-se por observar os traços da época do autor conjugados com os traços específicos de cada personagem. Enfim, o tradutor de teatro é aquele que, acima de tudo, visa a tradução teatral como uma atividade do discurso que só se realiza, plenamente, em cena.

Cristina Vinuesa (2013), no artigo sobre a sua tradução ao espanhol de uma peça francesa de Jean-Luc Lagarce, se propõe a descrever o processo tradutório "do texto como matéria 'horizontal' e dramática, até sua encenação ou 'verticalização' dramatúrgica"3 (Vinuesa, 2013, p. 283) [Tradução nossa], rendendo muito bem em imagens as diferentes sensações percebidas no processo tradutório para a cena, do "conforto" - posição horizontal - da leitura, fruição, de um texto dramático ao "desconforto" posição vertical - ao qual o tradutor do texto para a cena é impelido. Isso porque o tradutor precisa agir como outro profissional ligado à realização da peça, e deixar de lado a posição confortável de um meio no qual está acostumado a trabalhar: o texto escrito para ser lido.

Vinuesa justifica essa necessidade "peculiar" ao trabalho do tradutor de teatro contemporâneo por ser esse um gênero constituído por textos que "são pensados, elaborados e escritos na maioria das vezes a partir da cena"4 (Vinuesa, 2013, p. 283) [Tradução nossa]. Sendo "docentetraductora-actriz-directora", ela se questiona, a partir da sua experiência nas várias profissões às quais se dedica, sobre a razão pela qual quem traduz teatro, normalmente, não vem de uma escola de tradutores ou é um tradutor profissional, mas está sempre ligado à realidade teatral. É quase sempre um amigo ou alguém que está envolvido com a realização da peça,

\footnotetext{
3 “desde el texto como materia 'horizontal' y dramática, hasta su puesta en escena o 'verticalización' dramatúrgica".

4 "están pensados, elaborados y escritos mayoritariamente desde la escena".
} 
que conhece bem a língua estrangeira e que tem paixão pelo teatro. Ela, assim como todos os que se dedicam ao teatro, considera que

\footnotetext{
a arte dramática acarreta uma série de elementos que estão além da faceta filológica que à preciso ter muito bem em conta na hora de traduzir. Um texto teatral é basicamente uma partitura com espaço, tempo e personagens concretos, é um volume que toma forma e sentido na sua encenação, na sua verticalização. (Vinuesa, 2013, p. 285) [Tradução nossa] ${ }^{5}$
}

Sendo assim, o que o nosso projeto como grupo de pesquisa busca é que a tradução teatral comece a ser, como o é muitas vezes, não um produto "del azar", do caso, como Cristina Vinuesa testemunha no seu artigo, mas que o filão "estudos de tradução teatral" adquira o importante espaço que merece na formação de tradutores e de pesquisadores sobre tradução de textos artísticos (ou literários em geral). O nosso escopo e a novidade dessa metodologia aqui utilizada relativamente às demais metodologias de tradução teatral existentes, é que com nossa abordagem procuramos contornar a prática recorrente entre tradutores, atores e diretores teatrais que mantêm "cada um no seu quadrado e cada macaco no seu galho" e que, diante de traduções não adequadas para a cena, mutilam e reescrevem o texto recebido, levando ao público em geral regularmente adaptações de Sófocles, Shakespeare, Brecht e tantos outros. Essa prática nos parece o auge da tradução domesticadora (Venuti, 1995) sem critérios. O problema mais sério atacado e, acreditamos, solucionado pela metodologia aqui exposta é preservar a poética do texto original no texto traduzido e pensado para a oralização do ator. Tentamos segui-lo à "letra" (Berman, 2007) e não buscamos simplesmente adaptar a tradução para a encenação.

Nessa perspectiva, se o texto e a cena não são mais lugares distantes de um reino do descontínuo com fronteiras nítidas (Meschonnic, 2010, p. 21), podemos nos exercitar na redescoberta do pensamento-ação que é contínuo e que o texto carrega em si. Mas quando falamos de contínuo, falamos também do ritmo de uma ação textual. $O$ ritmo do texto é o ritmo

\footnotetext{
5 “[e]l arte dramático conlleva una serie de elementos más allá de la faceta filológica que hay que tener muy em cuenta a la hora de traducir. Un texto teatral es básicamente una partitura con espacio, tiempo y personajes concretos, es un volumen que toma forma y sentido en su escenificación, em su verticalización".
} 
da cena, o ritmo da cena é o da comunicação estabelecida com o público. O texto-cena é calcado na oralidade e é só através de um ritmo calculado e determinado como unidade de sentido que o espetáculo acontece (veja-se, por exemplo, a importância de sabermos, nos espetáculos que vamos apresentar, a duração da função). Evidentemente não estamos falando de métrica, de longas e breves ou coisas do tipo. Estamos mais uma vez nos referindo às teorizações de Meschonnic, neste aspecto também guiadas por Benveniste, entendendo o ritmo "como a organização e a própria operação do sentido no discurso. [...] Não mais um oposto ao sentido, mas a significação generalizada de um discurso" (Meschonnic, 2010, p. 43), pois a duração da enunciação cênica é parte da sua mensagem, assim como a assimilação rápida da mensagem por parte do espectador é parte da mensagem do próprio espectador para o ator afirmando: “Continue! Está ótimo!"

Para tanto, reunimos tradutores e atores, de forma que o texto traduzido seja verbalizado pelos atores diante de um "diretor de tradução", que escolhe as melhores opções cênicas e dramatúrgicas para o texto em questão.

Evidentemente, o processo exige do grupo todo um revisionismo da teoria de tradução aplicada aos textos teatrais, visto que estamos nos ocupando de sua função cênica. Desse modo, visamos prioritariamente às palavras e à sua exequibilidade vocal em fluxo contínuo de fala mais do que ao seu significado exato ou filológico; ao ritmo dramático mais do que à pontuação estabelecida no texto e na sintaxe original; ao uso rigoroso dos dêiticos e palavras coringas, tão necessários para a flexibilidade cênica.

\section{O processo colaborativo e funcional de tradução e a primeira versão de um texto}

No processo aqui descrito, um componente do grupo faz uma primeira versão da tradução do texto, no nosso exemplo a peça $E l$ borde, para o português. Em seguida, tal tradução é apresentada para a vocalização de um ator, na presença do grupo e, sobretudo, para o diretor de tradução. A partir dela, são feitas novas alterações, de modo que se contemplem importantes aspectos cênicos, textuais e também teóricos. Daí, após várias 
leituras, proposituras e discussão das melhores opções, são feitos os ajustes finais.

Segue a primeira versão do texto, que pode ser considerada normalmente uma tradução analítica (TOROP, 2010), voltada ao entendimento do prototexto (ou texto de partida) através de sua forma expressiva:

\section{El borde \\ Amancay Espíndola}

Yo soy hija única y mi infância fue muy linda, linda de veras. Feliz. Me casé a los diecisiete años. Eso no fue bueno. Nada bueno. Pero no estoy loca. Recién encontré en la biblioteca este libro: Las puertas de la percepción, de Aldous Huxley. Lo leíamos mucho en los '70. El tipo habla de la mescalina como algo liberador, para alcanzar la felicidad. Habla también de la esquizofrenia. Ja, con eso se libera más fácil uno, se vuelve loco y listo. Se va a la mierda. Tenía buena prensa la esquizofrenia cuando yo era joven. Había que estar loco para ser creativo, para hacer arte, una especie de romanticismo, de idealización de los estados alterados de la mente, que parecía que lo hacían a uno más creativo. $\mathrm{Y}$ si no eras loco, había que volverse loco con alguna sustancia. ¿De dónde salió eso? No tengo la menor idea. En esa época todos nos sentíamos creativos. Yo quería, bueno, quiero, pintar cuadros, $\mathrm{y}$ estar en un lugar verde. Estar en una isla verde, pintando cuadros verdes con mi nueva familia. $\mathrm{Y}$ voy a lograr la paz del cuerpo.

¿De qué estaba hablando? De la creación. El tipo dice que nada sale si no está primero adentro de uno, aunque tome mescalina. La voz que

\section{A borda \\ Amancay Espíndola}

Eu sou filha única e minha infância foi muito linda, linda de verdade. Feliz. Me casei aos dezessete anos. Isso não foi bom. Nada bom. Mas não estou louca. Ontem encontrei na biblioteca este livro: As portas da percepção, de Aldous Huxley. Muito lido nos anos setenta. $\mathrm{O}$ cara fala da mescalina como algo libertador, para alcançar a felicidade. Fala também da esquizofrenia. Já, com isso uma pessoa se livra mais fácil, se torna louco e pronto. Se vai à merda. Pegava bem a esquizofrenia quando eu era jovem. Tinha que estar louco para ser criativo, para fazer arte, uma espécie de romantismo, de idealização dos estados alterados da mente, que parecia que tornava uma pessoa mais criativa. E se você não era louco, tinha que se virar louco com alguma substância. De onde veio isso? Não tenho a menor ideia. Nessa época todos se sentiam criativos. Eu queria, bom, quero, pintar quadros, e estar em um lugar verde. Estar numa ilha verde, pintando quadros verdes com minha nova família. E vou conseguir a paz do corpo.

De que estava falando? Da criação. $O$ cara diz que nada sai se primeiro não está dentro de uma pessoa, embora tome mescalina. A 
uno tiene profundamente dentro de sí, lo que se es, profundamente adentro, puede que alguna vez salga, pero si no está, no sale nada. Y no hay mescalina que valga. Vaya a saber cuántos verdes tengo adentro, y por ahí salen dos o tres. O salen verdes que yo ni sé que tengo. Pero los verdes que no tengo, no salen, porque no están. Y que estamos solos, porque lo profundo nuestro no puede ser compartido, ¿me entiende? ¿Está entendiendo lo que le digo? ¿Adónde era que quería ir? Yo debería tener catorce años cuando leí este libro, entre los catorce, los quince, por ahí. Era mi libro de cabecera.

$Y$ si se atravesaran todas las puertas de la percepción con la mescalina, podríamos llegar a tener un conocimiento infinito. ¿Infinito para qué, digo yo? Porque si hay cosas escondidas en el cerebro que no salen a la luz sin la ayuda de alguna sustancia, ¿cómo se hace para poder estar en eso y también dentro de un orden? Porque las personas viven, trabajan, tienen que comer, tienen que ir al baño, tienen que cuidar a los bebés. ¿Y cómo se hace para tener un conocimiento infinito $y$ vivir todos los días?

A veces en los sueños veo cosas muy lindas. Otras, no, son cosas horribles, y uno se despierta y quiere desaparecer para no recordar. Y hay cosas horribles en la vida que uno tampoco quiere ver. ¿Se imagina a un tipo que agarra y degüella mujeres, o a una mujer que mata a alguien? En el momento de agarrar el cuchillo y metérselo en las costilla a otro hasta que se desangra. ¿Qué pasa en esa cabeza?

¿Sería uno capaz de matar a alguien en una situación extrema? voz que uma pessoa tem profundamente dentro de si, o que é, profundamente dentro, pode ser que alguma vez saia, mas se não está, não sai nada. E não tem mescalina que valha. Vai saber quantos verdes tenho dentro, e por aí saem dois ou três. Ou saem verdes que eu não sei que tenho. Mas os verdes que não tenho, não saem, porque não estão. $\mathrm{E}$ que estamos sós, porque o profundo nosso não pode ser compartilhado, entende? Está entendendo o que digo? Aonde era que queria chegar? Eu deveria ter quatorze anos quando li este livro, entre quatorze, quinze, por aí. Era meu livro de cabeceira.

E se se atravessassem todas as portas da percepção com a mescalina, poderíamos chegar a ter um conhecimento infinito. Infinito para quê, me pergunto. Porque se têm coisas escondidas no cérebro que não saem à luz sem a ajuda de alguma substância, como se faz para poder estar nisso e também dentro de uma ordem? Porque as pessoas vivem, trabalham, têm que comer, têm que ir ao banheiro, têm que cuidar dos bebês. E como se faz para ter um conhecimento infinito e viver todos os dias?

Às vezes nos sonhos vejo coisas muito lindas. Outras, não, são coisas horríveis, que te acordam e te dá vontade de desaparecer para não lembrar. E têm coisas terríveis na vida que uma pessoa tampouco quer ver. Já pensou um cara que agarra e degola mulheres, ou uma mulher que mata alguém? No momento de agarrar uma faca e enfiá-la nas costelas de outro até dessangrar. Que passa nessa cabeça?

Seria uma pessoa capaz de matar alguém em uma situação extrema? Tem gente que diz Eu nunca mataria 
Hay gente que dice Yo nunca mataría a nadie. No, yo nunca mataría a nadie en una situación normal, pero en una situación desbordada, con peligro para otro o para mí misma...

Y sí, me equivoqué. Pensé que los viejos ésos estaban en Mar del Plata, pero estaban en el departamento. Habíamos entrado a robar, nada más, y todo se complicó. Y el viejo empezó a atacar a Oska, quiso matar Oska. Oska estaba en peligro y yo quería salvar lo mío, y agarré el cuchillo y se lo metí en las costillas al viejo, y después a la vieja, porque gritaba mucho. Fueron quince puntazos, o más, y a la vieja otro tanto, porque a Oska... Yo a Oska lo amo.

Es la primera vez que me enamoré, realmente. Es el amor que se siente una sola vez en la vida. Mi amor están grande, y él es tan chiquito. ¿Usted lo vio? Es como un bebé, hasta tiene carita de bebé. Lo amo tanto... Y vamos a estar juntos cuando salgamos, y vamos a tener un varón, porque a él le encantan los chicos.

No me acuerdo qué había tomado. Ácido, me parece. Era una mezcla. Ya pedí perdón y me arrepentí, y lloré mucho, muchas veces. Pero el tipo dice que ni la mescalina, ni ninguna otra sustancia, pueden despertar lo que no está adentro de uno. ¿Y qué es lo que hay dentro de mí, entonces?

¿Me puedo ir? ninguém. Não, eu não mataria ninguém em uma situação normal, mas em uma situação desbordada, com perigo para outro e para mim mesma...

Já, me confundi. Pensei que esses velhos estavam em Mar del Plata, mas estavam no apartamento. Entramos para roubar, nada mais, e tudo se complicou. E o velho começou a atacar Oska, quis matar Oska. Oska estava em perigo e eu queria cuidar do meu, e agarrei a faca e a enfiei nas costelas do velho, e depois da velha, porque gritava muito. Foram quinze punhaladas, ou mais, e na velha outro tanto, porque Oska... Eu amo Oska.

É a primeira vez que me apaixonei, realmente. É o amor que se sente uma só vez na vida. Meu amor é tão grande, e ele é tão pequeno. Você viu? É como um bebê, tem até a cara de bebê. $\mathrm{O}$ amo tanto... E vamos a estar juntos quando saímos, e vamos ter um menino, porque ele adora os meninos.

Não me lembro que havia tomado. Ácido, me parece. Era uma mistura. Já pedi perdão e me arrependi, e chorei muito, muitas vezes. Mas o cara diz que nem a mescalina, nem nenhuma outra substância, podem despertar o que não está dentro de uma pessoa. E o que é que tem dentro de mim, então?

Posso ir? 


\section{A vocalização e a versão final}

Essa primeira versão do texto foi vocalizada por duas atrizes em performances sequenciais. As mudanças ocorreram visando à verbalização e à encenação. Buscávamos preservar, acima de tudo, a dramaturgia, ou seja, queríamos manter a partitura espacial e temporal do texto de saída, cuidando da construção de um personagem concreto.

No grupo composto por sete acadêmicas e duas atrizes, foi possível dar vazão à imaginação cênica e representar o texto tal como se fosse efetivamente um ensaio, ainda que de forma muito rudimentar. Nessa circunstância, a tradução proposta foi sofrendo modificações oriundas de uma busca pela espontaneidade necessária para sua exequibilidade cênica. O propósito era alcançar o maior desembaraço de fala com gestualidade, respiração e ritmo, mas sem sacrificar a correção filológica. ${ }^{6}$ Utilizamo-nos, de maneira geral, das etapas indicadas por Vinuesa (2013), a saber, a vocalização de cada palavra em seu contexto frasal, para se observar a manutenção do sentido, ritmo melódico e emocional ${ }^{7}$ proposto à personagem pelo autor simultaneamente; observação cuidadosa para não permitir mudanças de registro linguístico; obsessão por preservar as características verbais da personagem criada. ${ }^{8}$ Com a preocupação rítmica do texto cênico, ao traduzir, observamos até mesmo uma possível performance respiratória e articulatória da frase no corpo do ator. O ritmo, quando contemplado em macrossentido, faz até mesmo a crítica das categorias sintáticas e da pontuação estabelecida pelo editor e, desse modo,

\footnotetext{
6 "O ritmo mostra que o primado caduco do sentido se faz substituir por uma noção mais possante, mais sutil também, já que ela pode se realizar no imperceptível, por seus efeitos de escuta e de tradução: o modo de significar. No que a aventura da tradução e do ritmo são solidárias" (Meschonnic, 2010, p. $56)$.

7 "[...] o ritmo, como dado imediato e fundamental da linguagem, e não mais em sua limitação formal e tradicional, renova a tradução e constitui um critério para a historicidade das traduções, seu valor. Sua poética e sua poeticidade" (Meschonnic, 2010, p. 41).

8 A leitura e análise deste texto, tendo em vista a tradução para o teatro, foram realizadas a partir da abordagem por níveis cronotópicos descrita por Peeter Torop, indo além da análise exclusivamente linguística que considera o texto exclusivamente na sua superfície. Os três níveis cronotópicos considerados por Torop são "il cronotopo topografico, legato al tempo e al luogo di svolgimento dell'intreccio; [...] il cronotopo psicologico, legato al mondo soggettivo dei personaggi $[\mathrm{e}]$ il cronotopo metafisico, detto anche cronotopo della concezione autoriale, relativo all'interpretazione dell'autore o alla sua mentalità" (Torop, 2010, p. 19). Esses constituem, respectivamente, um mundo imaginado ou representado, um mundo vivenciado e um mundo concebido.
} 
"refaz a história da tradução" (Meschonnic, 2010, p. 43), impõe um outro saber e mostra que não basta o saber da língua, mas carece perceber, por exemplo, no acender de um cigarro, que ritmo, que palavras (dissílabas, trissílabas?) comporão um entorno talvez de ansiedade, de relaxamento, de tensão que farão uma única unidade falada, gestualizada e escrita.

Em trabalho coletivo, imaginativo e até físico, o texto-resultado é o que se segue. Optamos por apresentar o texto com notas as quais se constituem como comentários, propriamente ditos, à tradução.

\section{O limite ${ }^{9}$}

Amancay Espíndola

Sou ${ }^{10}$ filha única e minha infância foi muito legal, ${ }^{11}$ legal pra ${ }^{12}$ caramba..$^{13}$ Feliz. Me casei aos dezessete anos. Isso não foi bom. Nada bom. Mas louca ${ }^{14}$ não estou. Ontem encontrei na biblioteca este livro: As portas da percepção, de Aldous Huxley. Muito lido nos anos setenta. O cara fala da mescalina

\footnotetext{
9 O vocábulo borde, traduzido normalmente por "borda", "margem", "beirada" foi propositalmente revertido por "limite", provocando uma clara intertextualidade com o filme de Mário Peixoto, referência estética do cinema brasileiro.

10 Apagamento do pronome pessoal yo com vistas a dar um ritmo abrupto, tão necessário para o tom dramático proposto pelo monólogo. As duas vogais emitidas no castelhano yo soy se ajuntam em uma única vocalização, mas isso não se dá no português. Ao se pronunciar "eu sou", o emissor se obriga a respirar e parar no pronome "eu". Tal tom se atenua com a emissão do pronome, pois obriga o falante a fazer uma pausa indesejada e inadequada para o ritmo brusco que se deseja. O ritmo enfático se perde na respiração e fôlego que se toma para realizar vocalicamente o verbo.

11 Substituição da palavra linda por "legal". A expressão muy linda, típica do castelhano, soava de modo forçado. Entendemos que o entrave se devia ao fato de "linda", no português, ser um intensificador e dispensar o advérbio "muito". Os sinônimos levantados, "bonita", "bela", pareciam-nos fora de lugar. Além disso, a repetição da oclusiva " $\mathrm{t}$ " em "muito" e "bonita" pesava no ritmo, enquanto "bela" seria um registro elevado para o contexto. Optamos, portanto, pelo uso comum de "legal".

12 Optamos pelo uso da preposição em sua forma contraída, já autorizada pelos poetas modernistas e muito comum em textos publicitários e principalmente na fala fluida da oralidade.

${ }^{13}$ A tradução imediata da locução adverbial de veras, numa tradução automática, seria, sem dúvida, "de verdade". No entanto, estamos construindo uma personagem que faz referência clara aos anos setenta, pelo livro de Huxley e o contexto daquela década, enfim, carecia-se de marcar essa época na fala, o que não combina com a locução "de verdade" ou o advérbio "deveras". Daí optamos por uma gíria, "pra caramba", na tentativa de recuperar uma dicção que, embora não seja específica dos anos setenta, era, naquele período, muito usada.

${ }^{14}$ Um enfático pero inicia a frase em questão, mas a tradução desta não produz tal efeito no português. Por esse motivo, provocamos uma mudança de posição sintática nos elementos frásicos, com a intenção de provocar, pela topicalização, ênfase dramática, o que é marcado, também, pela sílaba forte de "louca".
} 
como um troço ${ }^{15}$ liberador, ${ }^{16}$ para alcançar a felicidade. Fala também da esquizofrenia. Aí, com isso, claro, o sujeito ${ }^{17}$ se solta mais fácil, vira ${ }^{18}$ louco e pronto, ${ }^{19}$ vai à merda. Caía bem ${ }^{20}$ a esquizofrenia, quando eu era jovem. Tinha que ${ }^{21}$ estar louco pra ser criativo, pra fazer arte, uma espécie de romantismo, de idealização dos estados alterados da mente, que parecia que fazia a gente mais criativa. E se você não era louco, tinha que se fazer de louco com alguma substância. De onde saiu ${ }^{22}$ isso? Não faço a menor ideia. $\mathrm{Na}^{23}$ época todos nos sentíamos ${ }^{24}$ criativos. Eu queria, bom, quero, pintar quadros, e estar em um lugar verde. Estar numa ilha verde, pintando

\footnotetext{
$15 \mathrm{O}$ vocábulo algo passou pela boca dos atores que produziram a verbalização do texto, mas não se sustentou. Queríamos um registro mais comum, menos pensado, mais improvisado. A palavra "coisa", para o contexto, pareceu-nos comum demais. A opção unânime foi "troço" pelo impacto consonantal que cria o encontro do " $\mathrm{t}$ ", oclusiva dental, com o " $\mathrm{r}$ ", vibrante sonoro.

${ }^{16}$ A primeira opção de tradução, "libertador", foi, na oralização, substituída pelo vocábulo homônimo do castelhano, que, no nosso entender, soava mais fluido - visto não estar travado pela oclusiva " $\mathrm{t}$ " e mais próximo do texto fonte. Na execução vocal, levava a vantagem de poder ser entendido, em português, de forma ambígua como "libera a dor".

17 A escolha na tradução do pronome indefinido uno em castelhano, de utilização mais coloquial, foi variada: "sujeito", "cara", "a gente", "pessoa", "figura". O motivo foi não ter achado em português brasileiro um pronome indefinido com a mesma força expressiva e o colorido próprio da linguagem do dia a dia. El tipo, expressão no presente original, foi traduzido por "o cara". Para marcar a diferença, variamos o uno. A variação foi motivada igualmente pela prosódia, visto que uno, vocábulo ligeiro e facilmente apagado na enunciação castelhana, não muda o ritmo da frase como seus equivalentes no português. Tentamos neutralizar o mais possível ao variar os termos.

18 Opção demorada: "ficar" ou "virar"? Decidimos pelo verbo "virar", devido ao movimento interno que ele marca semanticamente. O verbo "ficar", decididamente, é estático e não coaduna com a instabilidade da loucura; já "virar" é resultativo, coaduna com a expressão "e pronto".

19 O ritmo da fala do ator impeliu a uma pausa menos brusca que o ponto final. As orações se ligaram em razão do apagamento do pronome "se", que acarretou o uso da locução que remete à postura rítmica de um xingamento em língua portuguesa, escolha dramática e dramatúrgica de impacto.

${ }^{20}$ A tradução inicial propunha "pegava", no entanto, uma das atrizes sugeriu realçarmos a referência com o mundo teatral e seus disfarces. A esquizofrenia encarada como uma indumentária que no corpo do ser criativo "caía bem".

${ }^{21}$ Em lugar do castiço "precisava de", preferimos o vulgar "tinha que", preservando a prosódia castelhana.

22 A mudança de "vir" para "sair" foi sugestão de uma das atrizes. O verbo "sair" pode sugerir em cena, para o ator, uma auspiciosa expressão de espanto. Nesse caso a forma "saiu" é mais inesperada e dramática do que forma "veio". O mesmo se pode dizer da forma "faço" para a oração seguinte.

${ }^{23}$ Apagamento do dêitico, que foi remarcado com o locativo "na".

24 Retorno ao original, mais envolvente com a plateia, mais próximo, sem a generalização pelo indefinido "se".
} 
quadros verdes com minha nova família. Aí25 vou conquistar ${ }^{26}$ a paz do corpo.

$\mathrm{Do}^{27}$ que estava falando? Da criação. $\mathrm{O}$ cara diz que nada sai se não está primeiro dentro da gente, ainda que a gente tome mescalina. A voz que o sujeito tem muito lá dentro ${ }^{28}$ de $\mathrm{si}$, o que se é, bem lá pra dentro, pode ser que, alguma vez, saia, só que, ${ }^{29}$ se ela lá não está, não sai nada. E não tem mescalina que chegue. ${ }^{30}$ Vai saber quantos verdes eu ${ }^{31}$ tenho dentro?! Vai que saem dois... ou três... e que saem verdes que eu não sei que tenho... Mas os verdes que não tenho, não saem, porque lá não estão. ${ }^{32}$ É que estamos sós, porque o lá da gente ${ }^{33}$ não pode ser compartilhado, entende? Entende ${ }^{34} \mathrm{o}$ que digo? Aonde era mesmo que eu queria chegar? Eu deveria ter quatorze anos quando li este livro, entre quatorze, quinze, por aí. Era meu livro de cabeceira.

E se a gente atravessasse todas as portas da percepção com a mescalina, poderíamos chegar a ter um conhecimento infinito. Infinito pra quê... eu pergunto. Porque se têm coisas escondidas no cérebro que não saem à luz sem a ajuda de alguma substância e como se faz para poder estar nessa e também dentro de uma ordem? ${ }^{35}$ Porque as pessoas vivem,

25 Tradução da conjunção aditiva y com o advérbio "aí", locativo, mas com um sentido consecutivo. O texto não deixa claro se a relação da frase em questão com a anterior é de adição ou consequência, entretanto, no teatro, sempre se ganha com a ambiguidade.

26 Substituímos "conseguir" por "conquistar". Optamos por um termo semanticamente mais positivo, de forma que, no imaginário cênico, haja possibilidade para uma evasão e um sorriso. "Conseguir" nos pareceu mais voltado para o esforço do que para a vitória alcançada que, de fato, é o que sugere o verbo lograr.

${ }^{27}$ Trocamos "de" por "do", por este marcar mais enfaticamente o que estava sendo abordado.

28 Buscamos com a expressão "muito lá dentro" uma possibilidade gestual do ator. O advérbio "profundamente" é em português um tanto abstrato para o contexto.

${ }^{29}$ Eis uma opção por uma locução mais enfática do que o "mas", comumente vertido no caso do pero.

${ }^{30}$ Troca do "chegue" por "valha", uso mais frequente na fala do português.

31 Ênfase dramática por meio da inserção do pronome seguida da alteração da pontuação, para estabelecimento de um elemento surpresa sugerido no texto fonte.

32 O verbo "estar" exigiu a inserção do advérbio "lá".

33 Em um primeiro momento se optou pelo possessivo "nosso" colocado antes de "profundo", parecendo mais natural em português. Sucessivamente foi escolhida a locução "a gente", mais coloquial e utilizada na mesma colocação sintática do original.

${ }^{34}$ Houve a opção de inserir o pronome "você" na forma abreviada da fala e usar o verbo na forma finita eliminando o gerúndio, mais frequente e eficaz (por ser uma interpelação imediata) no português; achamos mais conveniente deixar sem o pronome, a decisão será do ator que fizer a cena.

35 "Nisso" da primeira versão foi trocado por "nessa", expressão coloquial muito frequente no português brasileiro. 
trabalham, têm que comer, têm que ir ao banheiro, têm que cuidar dos bebês. E como se faz para ter um conhecimento infinito e viver todos os dias?

Às vezes nos sonhos vejo coisas muito legais. ${ }^{36}$ Outras, não, são coisas horríveis, das que o cara ${ }^{37}$ acorda e tem vontade de desaparecer para não lembrar. E têm coisas $^{38}$ terríveis na vida que a pessoa não quer nem ${ }^{39}$ ver. Já imaginou um cara que agarra e degola mulheres, ou uma mulher que mata alguém? $\mathrm{Na}^{40}$ hora de agarrar uma faca e enfiá-la nas costelas dum ${ }^{41}$ outro até sangrar. Que é que ${ }^{42}$ tem $^{43}$ nessa cabeça? Seria uma pessoa capaz de matar alguém em uma situação extrema? Tem gente que diz Eu nunca mataria ninguém. Não, eu não mataria ninguém em uma situação normal, mas, numa situação limite, com perigo para outro e para mim mesma...

É, sim, me confundi. Achava ${ }^{44}$ que os velhos, eles ${ }^{45}$ estavam em Mar del Plata, mas estavam no apartamento. Entramos para roubar, só, e tudo se complicou. Ai ${ }^{46}$ o velho começou a atacar Oska, quis matar Oska. Oska estava em perigo e eu queria salvar o meu e agarrei a faca e a enfiei nas costelas do velho e depois da velha, porque ela ${ }^{47}$ gritava muito. Foram quinze punhaladas, ou mais, e na velha um outro tanto, porque Oska... Eu amo Oska.

É a primeira vez que me apaixonei, realmente. É amor que se sente sót8 uma vez na vida. Meu amor é tão grande e ele é tão pequetito. ${ }^{49}$ Você

\footnotetext{
${ }^{36}$ Cf. comentário 4.

37 Retorno ao indefinido do original.

38 Retorno ao original, apagamento do artigo definido para gerar suspense dramático.

39 Substituição do "tão pouco/ tampouco", menos frequente no português, pela dupla negativa, que logra ser mais comum e enfática.

40 Retorno à forma original, mais dramática.

${ }^{41}$ Forma enfática e contrata para o pronome indefinido, marcado pelo "de + um" e não com o "de".

42 Expletivo de alto valor dramático.

43 Recuperação de etapa anterior do discurso.

44 Forma mais natural no português.

45 Reduplicação, “os velhos, eles” de modo a gerar pausa dramática, hesitação.

46 Cf. comentário 18.

47 Inserção necessária do pronome: desambiguação do sujeito de gritar.

48 Inversão de "só" para dar ênfase dramática "só uma vez na vida" e não "uma vez só na vida" como no castelhano.

49 Tentativa de recuperar o sufixo castelhano, forma, de resto, também do uso do português.
} 
viu? É como um bebê, tem até carinha ${ }^{50}$ de bebê. Amo tanto ele... E vamos estar juntos quando sairmos e vamos ter um menino, porque ele adora os meninos.

Não me lembro o que tinha tomado. Ácido, eu acho. Era uma mistura. Já pedi perdão e me arrependi e chorei muito, muitas vezes. Mas o cara diz que nem a mescalina nem nenhuma outra substância podem despertar o que não está dentro da gente. E o que é que tem dentro de mim, então?

Posso ir?

\section{Considerações finais}

Eis, enfim, nossa pequena contribuição para a teoria da tradução de textos teatrais. O resultado, para o grupo, foi bastante satisfatório nos ensaios, porém, como afirmam Silva e Lopes (2005, p. 161), "Há sempre algo pra ser mexido, modificado e que muitas vezes você só descobre ao se deparar com o jogo da cena." O processo, o relato do caminho escolhido, os comentários, tudo isso vale somente pelo fato de que a tradução teatral atualmente vive um novo marco. Muitos - e respeitados - tradutores e pesquisadores de teatro já admitem o trabalho colaborativo nessas traduções como premissa de um resultado funcional e de qualidade cênica. Bons augúrios estes os que preveem a reunião de grupos antes separados: a filologia, os estudos da tradução e a dramaturgia. Bons tempos virão.

\section{Referências}

BERMAN, Antoine. A Tradução e a Letra, ou o albergue do longínquo. Trad. Marie-Hélène Catherine Torres; Mauri Furlan; Andréia Guerini. Rio de Janeiro: 7Letras/PGET, 2007.

CURRÁS-MÓSTOLES, Rosa; CANDEL-MORA, Miguel Ángel. La traducción de la especificidad del texto teatral: la simbología em $A$ man for all seasons. Entreculturas, n. 3, 2011, p. 37-58.

50 Recuperação do diminutivo do original, marcador de afetividade, contraste importante para o desfecho paradoxal do monólogo. 
ESPÍNDOLA, Amancay. El Borde. In: ARRECHE, A. M.; AGUILAR, J. M. Palabras en diálogo: la lectura puesta en acto. Buenos Aires: Leviatán, 2013. p. 96 - 99.

FERNÁNDEZ, Amalia Ortiz de Zárate. “'Escritura en voz alta': una propuesta de método de traducción teatral." In: FREIXA, Albert; GUIX, Juan Gabriel López (ed.). Actas del II Coloquio Internacional "Escrituras de la Traducción Hispánica". San Carlos de Bariloche, 2011, p. 133-152. Disponível em:

http://www.traduccionliteraria.org/coloquio2/actas.htm.

MERINO ÁlVAREZ, Raquel. Diez años de investigación sobre teatro traducido en España: el proyecto TRACE y los archivos de censura. Represura, n. 7, artículo n. 5, 2011. Disponível em: https://addi.ehu.es/bitstream/10810/10145/1/Represura.pdf. Acesso em: 27/11/2015.

MESCHONNIC, Henri. Poética do traduzir. Trad. Jerusa Pires Ferreira e Suely Fenerich. São Paulo: Perspectiva, 2010.

SILVA, Alexandra Moreira da; LOPES, Ângela Leite. Do outro lado do Atlântico: diálogo sobre teatro, tradução e tradução de teatro. Cadernos de Literatura Comparada, Porto, v. 12/13, p. 147-161, 2005.

TOROP. Peeter. La traduzione totale. Trad. Bruno Osimo. Rev. Ksenija Eliseeva. Milano: Hoepli, 2010.

VENUTI, Lawrence. Invisibility. In: The Translator's Invisibility: a history of translation. London, New York: Routledge, 1995. p. 1-42.

VINUESA, Cristina. La traducción teatral contemporánea: ¿una traducción literaria, escénica, sociodiscursiva, corporal? Ilustración a través de Juste la fin du monde de Jean-Luc Lagarce. Estudios de Traducción, Madrid, v. 3, p. 283-295, 2013.

Resumo: Neste trabalho, pretendemos elucidar um método de tradução do texto teatral cujo objetivo é contemplar suas várias facetas, desde a poesia e forma do texto até sua performance e caráter cênico. A fim de que tais aspectos sejam levados em consideração, o GTT/CNPq — Grupo (de Pesquisa) de Tradução Teatral tem optado pelo processo colaborativo, em que participam tradutores, atores e um "diretor de tradução". Esse método 
visa também à apreciação e aplicação de teorias de tradução já desenvolvidas. Apresentamos, para explicitar nosso trabalho, a tradução comentada do monólogo intitulado El borde, escrito pela argentina Amancay Espíndola.

Palavras-chave: tradução colaborativa, monólogo, El borde, Amancay Espíndola.

\begin{abstract}
In this work, we intend to illustrate a translation method of theatrical texts whose purpose is contemplating various aspects: not only the poetry and form of the text but also its performance and scenic characters. Considering such features, the group-GTT/CNPq, Grupo (de Pesquisa) de Tradução Teatral-has adopted the collaborative process, involving translators, actors and a "translation director." Such method intends also assessing and implementing the translation theories already developed. We present, to explain our work, a commented translation of the monologue titled El borde, written by the Argentine Amancay Espíndola.

Keywords: collaborative translation, monologue, El borde, Amancay Espíndola.
\end{abstract}

